\title{
Batı Nil Virüs Enfeksiyonu
}

\author{
Eda Dinç, Yakup Yıldırım \\ Mehmet Akif Ersoy Üniversitesi, Veteriner Fakültesi, Viroloji Anabilim Dalı, Burdur
}

Geliş Tarihi / Received: 15.08.2016, Kabul Tarihi / Accepted: 28.10.2016

\begin{abstract}
Özet: Batı Nil Virusu (BNV) kanatlılar, atlar, insanlar ve diğer memeli hayvanlarda nöropatik hastalıklara neden olan, eklem bacaklılarla (arhtropotlarla) nakledildiği için arbovirus olarak tanımlanan Arthropod Borne virus sınıfındadır. Doğal yaşam döngüsü Culex cinsi sivrisinekler ile evcil ve yabani kuşlar arasında olan etkenin, atlar başta olmak üzere insanlar ve diğer memeliler düşük viremi seviyesi ile rastlantısal konaklarıdır. Özellikle son yıllarda baraj göllerinin artması ve sulu tarım yapılan alanların yaygınlaşması sonucu, sokucu sinek popülasyonlarındaki artışa bağlı olarak bunlar aracılığı ile aktarılan çeşitli insan ve hayvan enfeksiyonlarındaki artış dikkat çekici boyutlara ulaşmıştır. Yapılan bu derlemede insan ve hayvan sağlığı açısından önemli olan BNV enfeksiyonu ile ilgili bilgiler verilmiştir.
\end{abstract}

Anahtar kelimeler: Batı Nil Virüs(BNV), arbovirus

\section{West Nile Virus Infection}

\begin{abstract}
West Nile Virus (WNV), poultry, horses, humans and other mammals causing neuropathic diseases, by arthropods (with robot that arhat) as defined for arbovirus transmitted is class Arthropod Borne Virus. Flavivirus is located in the Flaviviridae family. Factor between domestic and wild birds, the natural life cycle of the Culex species of mosquitoes, people, especially horses and other mammals are incidental hosts with a low level of viremia. The WNV infection and many arbovirus infections, symptoms and medical history information while helping to diagnosis, laboratory tests should be done with a certain diagnosis. Particularly the increase in recent years in the reservoir as a result of the expansion of the area under irrigation due to the increase in biting fly populations, the increase in human and animal infection transmitted through them reached remarkable sizes. Due to the lack of a safe and effective WNV vaccine, precautions should be taken in the social and individual levels to be kept under control and to prevent the disease. İnformation about this study that are important for human and animal health WNV infection is provided.
\end{abstract}

Key words: West Nile Virus (WNV), arbovirus

\section{Giriş}

Batı Nil virusu ilk kez 1937 yılında Uganda'nın kuzeyindeki Batı Nil bölgesinde 37 yaşında ateşli hastalık geçiren bir kadının serumunda tespit edilmiştir [77]. Batı Nil Virusu (BNV) kanatlılar, atlar, insanlar ve diğer memeli hayvanlarda nöropatik hastalıklara neden olan, eklem bacaklilarla (arthropotlarla) nakledildiği için arbovirus olarak tanımlanan Arthropod Borne virus sinifindadir. Arboviruslar arasinda Bunyaviridae, Flaviviridae, Togaviridae, Reoviridae ve Rhabdoviridae virus ailesinde yer alan 500'ün üstünde virus bulunmaktadır. BNV günümüzde yeniden güncellik kazanmış olan, doğal yaşam döngüsü kanatlılar ve sivrisinekler arasında süregelen bir RNA virusudur [57,59].

Batı Nil Virusu 300'ün üstünde kuş türü ve enfekte kuşları 1sıran sivrisinekler tarafindan doğada taşınır. Virusun doğal geçişi, arthropod-enfekte kuşlar-arthropod döngüsüyle meydana gelmektedir.
Kuşlar etkenin replike olduğu birincil konaklardır. Özellikle kırlangıç, güvercin, tavuk ve kazlar da yüksek prevelans söz konusudur [27]. BNV doğada özellikle Culex cinsi sivrisinekler ile evcil ve yabani kuşlar arasında sirküle olmaktadır $[25,26]$. Virusun doğal rezervuarı kuşlardır. Bundan dolayı virusun bir bölgeye ilk kez veya tekrarlayan girişlerinde özellikle göçmen kuşların önemli rolü vardır. Enfekte sivrisineğin 1sırdığg kuşlarda yüksek ve uzun süreli viremi oluşur. Gelişecek insan epidemileri ani kuş ölümlerine bakılarak öngörülebilinir $[31,59]$. Insan ve atlar, dokularında yeterli seviyede virus üremesi olmadığından ve virusu diğer konaklara aktaramadıklarından dolayı son konaktırlar $[57,59,60]$. Atlarda ve insanlarda k1sa viremi döneminin aksine, yabani veya evcil kuş türlerinde yüksek ve uzun süreli viremi düzeyi oluşur [14,41]. Bu derlemenin amacı, insan ve hayvan sağlığı açısından önemli olan BNV enfeksiyonu ile ilgili bilgiler vermektir. 


\section{Dünya ve Türkiye'de BNV Enfeksiyonunun Durumu}

Literatürde kayıtlı ilk epidemi 1951 yılında İsrail'den bildirilmiş olup, ardından 1954 ve 1957 yılları arasında salgınlar görülmüştür. 1957'deki İsrail salgınında yaşlı hastalarda meningoensefalit etkeni olarak BNV gösterilmiş. Sonraki yıllarda Fransa'da, 1974 yılında Güney Afrika'dan salgınlar bildirilmiştir. İspanya'da, Rusya'da, Güney Afrika'da ve Hindistan'da takip eden yıllarda nadiren de olsa benzer salgınlar görülmüştür [68].

Hastalık Kontrol ve Korunma Merkezi (Centers for Disease Control and Prevention, CDC) tarafindan yapılan çalışmalarla, bu suşun 1998 yılında İsrail'de dolaşan virus ile homolog olduğu belirlenmiş ve etken Batı Nil virusu olarak tanımlanmıştır [36].

1999 yılına kadar BNV'nin coğrafi dağılımı Afrika ülkeleri, Hindistan, Ortadoğu, Batı ve Orta Avrupa ile sınırlı olmasına karşın; virus 1999'da Amerika Birleşik Devletleri'nde New York şehrinde ilk kez saptanmış ve geçen zaman içinde tüm k1taya hızla yayılarak önemli bir sağl1k sorunu haline gelmiştir [33].

2002 y1lında Amerika'daki BNV vakalarında çarpıcı ve beklenmedik bir artış olmuş 4156 insan enfeksiyonu vakası ile 284 kişinin ölümüne sebep olmuştur [62].2003 y1lında bildirilen sayı ise 9122 olup, 223 olgu ölümle sonlanmıştır [79]. ABD'de gerçekleşen bu epidemi, batı yarımkürede bugüne kadar bildirilmiş en büyük arboviral menengoensefalit epidemisi olmasının yanı sıra en büyük BNV meningoensefalit epidemisidir [68].

Ülkemiz, virusun çok çeşitli ekosistemlerde var olabilme yeteneği sayesinde yeni coğrafi alanlara yayılma potansiyeli ve endemik bölgelerle komşuluğu göz önüne alındığında birçok arboviral enfeksiyonun görülme olasılığ 1 yüksek riskli bölgeler arasında yer alır [84].

BNV Türkiye'de insan salgınlarında bildirimi zorunlu hastalıklar arasında yer alır [13]. BNV yüksek riskli bir patojen olduğundan dolayı tanı genellikle referans laboratuar ile sinırlı olsa da virusun üretilmesini gerektirmeyen testlerin yapılmasında klinik mikrobiyoloji laboratuarları da rol üstlenebilir.
Ülkemizde değișik yıllarda BNV ile ilgili yapılmış çalışmalarda $[27,34,50,61,63,73]$ enfeksiyonun seroprevalansı insanlarda $\% 0.9$ ile $\% 47.8$ oranları arasında, hayvanlarda ise $\% 1$ ile $\% 37.7$ oranlar1 arasında tespit edilmiştir.

\section{Etiyolojisi}

\section{Batı Nil Virusunun Sınıflandırılması}

Batı Nil Virusu, Flaviviridae familyasından Flavivirus genusunda yer alan nöropatik bir arbovirustur. 10 serolojik alt gruba ayrilan genus tek zincirli ve pozitif polariteli RNA taşır. Etken aynı zaman Japon ensefalit virusu (JEV), Saint Louis encephalitis virusu (SLEV), Murray Valley encephalitis virus (MVEV), Koutango virus (KOUV), Cacipacore virus (CPCV), Alfuy virus (ALFV), Yaounde virus (YAOV), Usutu virus (USUV) ve Kunjin virus ve BNV içeren JEserokompleksi içinde yer almaktadır $[13,57,59,60]$. Özellikle Kunjin virus antijenik ve genetik benzerlik yönünden BNV'nin alt tipi olarak tanımlanmaktadır [55].

Batı Nil Virusu izolatlarının zarf proteinlerindeki aminoasit dizilim değişiklikleri ile filogenetik analizler ve meydana gelen delesyonlara göre 5 farklı genetik kökeni tespit edilmiştir.

İnsanlarda önemli hastalıklara köken 1'e ait BNV izolatları neden olmaktadır.2 alt grubu (clade 1a, clade 1b) tesbit edilen köken 1; Asya, Avrupa, Amerika, Avustralya ve Afrikadan izole edilmiştir [31,57,69].

Madagaskar, Güney Afrika ve 2010 yılından sonra Avrupa'da tespit edilen BNV izolatlarınında köken 2'ye ait olduğu belirlenmiştir. Birinci kökene ait suşların diğer kökenlerdeki izolatlara göre daha virulant olduğu tespit edilmiştir [17,69].

Son yıllarda Avustralya'dan köken 3 izolatları, Rusya'da farklı türlerden köken 4 ve Hindistan'dan köken 5, BNV virus izolatları tespit edilmiştir [9].

İzolatlar arasındaki patojenite farklılıklarının virusun $\mathrm{E}$, prM ve yapısal olmayan proteinlerdeki nükleotid dizilimlerindeki farklılıklardan kaynaklandığ tahmin edilmektedir [59,69,81]

\section{Batı Nil Virusun Yapısı ve Genomu}

BNV virionları sferik ikozahedral simetriye sahip ve 45-50 nm çapındadır. Pozitif polariteli, tek zin- 
cirli RNA kapsayan virus yaklaşık 12000 nükleotite sahiptir. Virion zarflı olduğu için dış ortamlara dayanıklı değildir. Isı, lipid çözücülerle veya deterjan içeren dezenfektanlar içinde süratle inaktive olur [69]. Virusun yapısında üçü yapısal (kapsid $[\mathrm{C}]$, zarf [E] ve premembran [prM]/membran [M]), yedisi yap1sal olmayan (NS1, NS2a, NS2b, NS3, NS4a, NS4b ve NS5) ve viral replikasyona katılan toplam 10 protein vardır [57,59,69].Viral poliproteinler çoklu transmembran alanları içerdiğinden, olgun viral proteinlerin poliproteinlerden kesilme işleminden sonra $\mathrm{C}$, NS3 ve NS5 proteinleri sitoplazmik alanda, PrM, E ve NS1 proteinleri lümende, NS2A, NS2B, NS4A ve NS4B proteinleri ise endoplazmik retikulumun çift zarlı membranı içerisinde lokalize olur [46,47].

Hücre içi viral RNA çoğalmasında yapısal olmayan proteinlerin görev aldı $\breve{g}_{1}$ belirlenmiştir. BNV ile enfekte memeli hücrelerinde çok miktarda sentezlenen yapısal olmayan NS1 proteininin, bu virusa karşı oluşan immün yanıtın sinyal yolaklarının düzenlenmesinde rol oynadığı belirlenmiştir. NS5 geninin ürünü olan viral RNA-bağımlı RNA polimeraz viral genomun replikasyonundan sorumludur. Virusun immunolojik görevi yapısal en önemli proteini olan E, aynı zamanda etkenin hemaglütinasyon ve hücreye tutunmasını sağlayan en önemli virulans faktörüdür $[57,59,69,82]$.

\section{Virus Replikasyonu}

Batı Nil Virusunun hücre yüzey reseptörlerine adsorbsiyonu ile başlayan replikasyon siklusu invitro şartlarda karmaşıktır. Virusun DC-SIGN, DC-SIGNR ve integrin $\alpha v \beta 3$ gibi hücre adezyon molekülleri olduğu belirlenmiştir [10]. Hücre yüzeyine tutunan etken klatrin endositoz yoluyla hücre içerisine girer. Virusun yapısal E proteininin değişimi ile hücre ve virus zarları birleşir bunu müteakiben nükleokapsit sitoplazmaya girer. mRNA görevi gören virusun, pozitif polariteli RNA's1 öncül proteinlerin sentezinde görev alır. Bunu takiben viral ve hücresel proteazların birlikte çalışması ile virusun yapısal (C, prM, E) ve yapisal olmayan proteinleri sentezlenir. Protein sentezinde konak hücrenin endoplazmik retikulumundaki (ER) sinyal peptidaz enzimi ile etkenin NS3 proteazı görev alır. Virus nükleik asit replikasyonu; NS5 'in kodlandığ 1 RNA polimeraz enzimi vasıtasıyla pozitif sarmaldan yeni viral nükleik asidlerin sentezinde kalıp görevi görecek negatif polariteli RNA sentezlenir. Virusun yap1larının sentezini takiben indüklenen endoplazmik retikulum kaynaklı membran içinde virus toparlanması olur. İmmatür virionlar tomurcuklanarak hücre sitoplazmasına geçerler $[12,47]$.

İmmatür vironda $\mathrm{E}$ ve prM proteinleri bulunur. Hücre lümenine birakılan E proteinleri ER sekresyonları ile düzleşerek dimerik yapı şeklinde virusun yüzeyinde yer alırlar. Virusun yüzeyinde bulunan prM proteinleri konak serin proteazları tarafindan kesilerek virusun olgunlaşma süreci tamamlanır ve ekzositoz ile hücreden dişarı bırakılır. Protein sentezinin (E, prM, vs.) yeteri miktarda yapılmadığ 1 durumlarda viron olgunlaşması şekillenmez [66].

\section{Epidemiyoloji}

Mısır'da keşfedilen virus yalnızca sivrisineklerden izole edilmiştir. Diğer artropodlardan izole edilmemiş olması nedeniyle sivrisineklerin birincil vektör oldukları görüşü ileri sürülmüştür. $\mathrm{Bu}$ görüş, konaktan beslenmeyle başlayan enfeksiyonun vektör döngüsünü yalnızca sivrisineklerin sürdürebildiğinin ve virus bulaşının sivrisineklerin 1sırmasıyla aktarılmaya devam ettiğinin gösterilmesiyle kanıtlanmıştır. Birincil vektörün Culex cinsi sivrisinekler olduğu ortaya konulmuştur $[58,79]$. Sonra ki yıllarda birçok ülkede (İsrail, ABD, Rusya, Fas, Güney Afrika, Sudan, Cezayir, Romanya, Çek Cumhuriyeti, Tunus, Kongo, Fransa, Kanada ve İtalya) teşhisi yapılan hastalığın yayılmasında ayrıca yabani kuş göçlerinin de sorumlu olduğu kabul edilmektedir [51].

Kuş türleri Batı Nil Virusunun çoğaldığı birincil ana konak olarak kabul edilir. Endemik bölgede, virusun yaşam döngüsü sivrisinekler ve kuşlar arasında gerçekleşir. İnsanlar, diğer memeliler ve özellikle atlar BNV için alternatif konak olabilirler; bunlara enfeksiyonun asıl geçiş yolu enfekte sivrisineklerin 1sırmasıyla olur. Ayrica virusun; intrauterin yolla veya emzirme yoluyla anneden yavruya ve kan transfüzyonu veya organ nakli ile bireyler arasında yayılabileceği birkaç çalışmada gösterilmiştir $[1,20]$.

Çoğu insanda enfeksiyon asemptomatik seyrederken vakaların \%20-30'unda Batı Nil ateşi bu vakaların da yaklaşı \% $\% 1$ 'inde BNV ile karakterize 
ensefalit, menenjit, akut flask paralizi ve hatta uzun vadeli nörolojik sekeller şekillenir [45].

BNV suşları en az 5 genetik soy içine gruplandırılmıştır [50]. Köken 1 Asya, Avrupa, Kuzey Amerika, Afrika ve Avustralya'da izole edilen antijenik olarak farklı izolat grublarını içermektedir. Bu nesil en az iki farklı dala ayrılır; Batı Nil Virusu-1a Afrika, Avrupa, Kuzey Amerika ve Asya'da esas olarak bulunur [52]. BNV 1-b ise Avustralya'da yer alır. Hindistan izolatlarını içeren üçüncü bir dal (1c) köken 5 olarak sınıflandırılmıştır[11]. Sahra altı Afrika ve Madagaskar'da izole edilen suşlarda köken 2'de yer alır. Bu suşlar son zamanlarda Avrupa ülkelerinde de görülmüsstür. Son yıllarda Macaristanda yırtıc1 kuşlarda bu suşlar tespit edilmiştir [6]. Macaristan ve Güney Afrika suşlarına göre, 2007 yılında tespit edilen Rus soyundan farklı köken 2 suşları tespit edildi $[3,74]$. Köken 3 memelilerde patojenik olan ve Güney Moravia ile Çek Cumhuriyeti'nde belli Culex ve Aedes türü sivrisineklerle dolaşan 'Rabensburg virusunu" içerirken [5], köken 4 Dermacentormarginatus kene türü ile taşınan Kafkasya'da izole edilen suşları içerir [49].

\section{Patogenez}

BNV türleri arasındaki virulans farklılığı, laboratuar bulguları ile doğrulanmış insan vakalarının azlığ 1 ve klinik semptomların hafif seyri nedeni ile BNV'nin patogenezi ile ilgili çalışmalar sınırlıdır. BNV yaygınlaşması ve patogenezi ile ilgili bilgilerimizin çoğu kemirgenlerde yapılan çalışılmalardan elde edilmiştir [18]. Ancak bu gözlemler yine de virusun insan vücudunda oluşturduğu doğal enfeksiyon seyrini tam olarak gösterememektedir. Virusu taşıyan sinek tarafindan isırılma sonucunda organizmaya giren BNV lenf nodüllerine yerleşir ve primer replikasyonunu burada gerçekleştirir $[16,18,44]$. Birkaç gün süren düşük düzeyli viremi ile birlikte IgM'ler oluşur $[31,57,59,69]$. Karaciğer, böbrek ve dalak gibi organlara viremi sonucu ulaşan virus bu organlara yerleşir. Viremi aşamasında beyne ulaşan virusun kan-beyin bariyerini ne şekilde geçtiği tam olarak bilinmemekle birlikte aksonal taşınma ile veya endotel replikasyon ile bu bariyeri geçtiği düşünülmektedir. MSS'ye ulaşan virus ciddi immun patolojik bozukluklar ile apoptozise neden olur. Nörovirulan olan BNV virusu interferon üretimine karışan genleri, MHC sınıf I ve II antijen sunumunu, T hücre transferini ve apoptozis mekanizmasını bozar. Enfeksiyonun viremi düzeyi ve süresini bireyin yaşı, kronik hastalıkları ve immun durumu belirler $[35,39,57,59]$.

Enfeksiyona bağlı ölüm vakalarına yapılan postmortem patolojik muayenelerde beyin ve medulla spinaliste nöron dejenerasyonu ile peteşiler görülür. Prognozun iyi olduğu durumlarda iyileșme görülebilir ama aylar /haftalar sonra hastalığın tekrarlayabileceği göz önünde bulundurulmalıdır [40].

\section{Tanı}

BNV enfeksiyonu ve birçok arbovirus enfeksiyonunda, anamnez bilgileri ve semptomlar teşhise yardımcı olur. Kesin tanının laboratuar testleri ile yapılması gerekir. Çünkü BNV benzeri klinik semptomlar gösteren, ensefalit, aseptik menenjit ve ateşli hastalık etkeni birçok patojen bulunmaktadır. $\mathrm{Bu}$ durum ayırıcı tanıda göz önünde tutulmalıdır $[28,69]$.

BNV enfeksiyonunda şüphelenilen durumlarda; beyin omurilik sıvısı (BOS), serum ve diğer vücut sıvılarından alınan marazi maddeler hastalığın teşhisi için laboratuara gönderilebilir. Enfeksiyonun serolojik teşhisinde JE kompleksi ile çapraz reaksiyon verebileceği unutmamalıdır. Bu amaçla BNV enfeksiyonunun laboratuar teşhisinde virus izolasyonu, virus nükleik asidinin veya viral antijenlerin saptanması ve etkene karşı oluşan immun yanıtın belirlenmesine yönelik hemaglutinasyon inhibisyon (HI), komplement fikzasyon (KF), IgM antibody-capture enzyme-linked immunosorbent assay (MAC-ELISA), plak redüksiyon nötralizasyon testi (PRNT) ve PCR gibi spesifik teknikler kullanılmalidir [33].

\section{BNV hastalığının teşhisinde kullanılan başlıca metotlar}

\section{Virus İzolasyonu}

Virus izolasyonu virusun tanısı için altın standart olarak kabul edilmektedir. BNV izolasyonu için hem memeli hem de sivrisinek dokularından türetilmiş hücre hatları kullanılmaktadır [22,23].

\section{Antijen Testleri}

Tarama çalışmalarında kullanılmak üzere kanatlılarda ve sivrisineklerde viral antijenlerin saptanma- 
S1 amacıyla geliştirilen farklı yöntem ve duyarlılıklara sahip ticari test sistemleri vardır [23].

\section{Serolojik Testler}

İnsanlarda BNV tanısında "spesifik antikor tespitine dayalı yöntemler" yaygın olarak kullanılmaktadır. Flaviviruslar arasında görülen antijenik çapraz reaksiyonların varlığı, serolojik yöntemlerin klinik önemini sınırlandırmaktadır. Oldukça özgül zarf proteinine (E) karşı oluşan nötralizan antikor yanıtına dayalı yöntem, sıklıkla daha az özgül olan membran proteinine ve yapisal olmayan proteinlere karşı oluşan antikor yanıtına dayalı test ile birleştirilir. [23,71]. Bu bağlamda BNV enfeksiyonunun serolojik teşhisinde başlica; indirekt-immunofluoresan (IF), hemaglutinasyon-inhibisyon (HI), komplement fikzasyon (KF) ve altın standart yöntem olarak kabul edilen plak redüksiyon nötralizasyon testi kullanılmaktadır [36,71].

İnsanlarda BNVenfeksiyonlarının teşhisinde serolojik testler uygulamas1 durumunda; bireyin daha önce geçirdiği arboviral enfeksiyonlar, bunlarla ilgili aşılanmalar, BNV'nin bölgesel epidemiyolojisi ve hastalığın endemik seyrettiği bölgelere yapılan seyahat bilgileri bir bütün olarak değerlendirilmelidir [29,82].

\section{Moleküler Testler}

BNV genomu arthropod, memeli ve kanatliların serum, doku ve plazmalarında enfeksiyon sonras1 2-3 ile 14-18 günler arasında saptanabilir. Moleküler yöntemlerin analitik duyarlılığı yüksektir. BNV enfeksiyonunun tanısında tarama amaciyla siklıkla kullanılan yöntem viral RNA sekanslarının kullanıldiğ 1 reverse transcription-polimeraz zincir reaksiyon (RT-PCR) yöntemidir.[75].

\section{Laboratuvar Bulguları}

BNV enfeksiyonunun laboratuar bulgularında spesifik bir özellik yoktur. Ancak periferik kan tablosundaki toplam lökosit sayısı normal yada lenfositopeni şekillenmiş veya anemik bir tablo gelişmiş olabilir. Periferik kan tablosunda sola kayma ve monositoza rastlanabilir. Eritrosit sedimentasyon hızı çoğu zaman normaldir. Eozinofili genellikle görülmezken, trombosit sayısı normal sinırlardadır. Karaciğer tutulumu sık olmamakla birlikte na- dirende olsa transaminazlar yükselebilir, bilirübin yüksekliği çok nadirdir, alkalen fosfataz düzeyleri normal sınırlardadır. BNV enfeksiyonunda özellikle ensefalit klinik tablosu gösteren vakalarda hiponatremi oluşabilir ve bu durum çoğu zaman Lejyoner enfeksiyonu ile karışmasına sebep olur [65]. Hastalığın MSS formunda diffüz bilateral anormallikler elektroensefalografide (EEG) belirlenebilir. BOS berraktır, pleositos gösterir ve genellikle BOS'taki hücre sayısı 45-1720 hücre/mm3civarında olur ve BNV enfeksiyonlarının erken dönemlerinde bu hücrelerin içinde de lenfositlerin belirgin bir hakimiyeti vardır [65].

BOS protein düzeyi yüksek seviyelere ( 1000 $\mathrm{mg} / \mathrm{dL})$ ulaşabilir. BOS' dan tespit edilen lenfosit sayısı artışı $(>\% 50)$ ve protein konsantrasyonundaki artış tanıya yardımcı olur [15,33]. Manyetik rezonans görüntüleme (MRG) çoğu hastada normal olmasına rağmen, talamusta, ponsta T2 ağırlıklı sekanslarda, beyaz madde sinyal dansitelerindeki artış görüntülemede önemli bulgudur.

\section{Ayırıcı Tanı}

BNV enfeksiyonunun semptomları MSS tutulumu ile seyreden birçok viral hastalık ile aynıdır. Ayrıca arbovirus enfeksiyonlarının serolojik teşhisinde çapraz reaksiyonlar görülme ihtimalinden dolay1 ayırıcı teşhis önem kazanmıştır. Arbovirusların neden oldukları enfeksiyonların ayırıcı teşhisinde coğrafi dağılım, hastanın yaşı, bölgedeki endemik durum vs. göz önünde bulundurulmalıdır. BNV enfeksiyonu insanlarda genellikle yetişkinlerde veya yaşlilarda görülmesi oluşan vakaların yaklaşık \%10'unun ölümle sonuçlanması bakımından diğer flavivirus enfeksiyolarından farklılık gösterir. Etiyolojisi belirlenemeyen aseptik menenjitli hastaların gövdelerinde makülo papüler döküntülerin görülmesi, ensefalit veya hepatit semptomlarının belirlenmesi halinde hasta BNV yönünden araştırılmalıdır [53,54].

BNV özellikle epidemik olmadığı bölgelerde St. Louis virus ensafaliti vakaları ile karışabilir. Ayrıca insanlarda görülen aseptik menenjit vakalarına neden olan enterovirus enfeksiyonlarından ve ensefalite neden olan diğer viral enfeksiyonlardan (herpes simpleks virus vs.) ayrımına dikkat edilmesi gerekir [65]. 


\section{Klinik}

BNV enfeksiyonu insanlarda, subklinik enfeksiyondan ölüme kadar değişik klinik tablolara sebep olmaktadır. Nörolojik bulguların gelişmediği olgular Batı Nil ateşi olarak adlandırılırken, meningoensefalit gibi nörolojik bulguların geliştiği olgular ise Bat1 Nil meningoensefaliti olarak adlandırılmaktadir.

Batı Nil Virusunun neden olduğu hastalık vakalarının yaklaşık \%80'i asemptomatik seyrederken; \%20'si ise inkübasyon periyodu 2-15 gün arasında olan grip benzeri hastalık şeklinde ortaya çıkar [4]. Olguların \%1'inde ise ensefalit, menenjit ve akut flask paralizi ile seyreden ve ölümle sonuçlanan nöroinvaziv enfeksiyon gelişebilir [24,57,60,81].

En önemli klinik belirtiler baş ağrısı, ateş, titreme, kırgınlık, halsizlik, kas ve eklem ağrısı, retroorbital ağrı, bulant1, kusma, ishal, genellikle çocuklarda makülopapüler veya roseolar döküntü şeklindedir $[80,82]$. Lenfadenopati hastaların büyük çoğunluğunda saptanır. Çok şiddetli vakalarda genel durum bozuklukları ile birlikte olgularda, uyuşukluk, optik nörit, vücut kaslarında zayıflık, myelit, boynu dik tutamama, zihinsel karışıklık, mental durum değişikliği, kas titremeleri, hareket bozuklukları, koma, konvülziyonlar ve paralizi gelişebilir $[24,81,82]$.

BNV enfeksiyonuna bağlı ensefalit vakaları; diyabet, kardiyovasküler rahatsızlıklar, hepatit $\mathrm{C}$ virüs enfeksiyonları ve immünsupresyon gibi hastalıklarla birleşirse ölüm riski $\operatorname{artar}[48,72]$. Genç ve çocuklarda yaşlılara (50 yaş ve üzeri) oranla daha az görülen $\mathrm{BNV}$ hastalığında mortalite oranı \%3-15 civarındadır $[38,81]$.

İnsanlarda olduğu gibi hayvanlarda da enfeksiyon genellikle subklinik seyretmekte ve vakaların sadece \%10'unda klinik semptomlar gelişmektedir [14].

Kedilerde köpeklere nazaran Batı Nil virusu hastalığının klinik bulguları daha belirgin görülür. Klinik hasta hayvanlarda yüksek ateş, letarji ve nörolojik bulgular tespit edilebilir. Ayrıca kedilerin BNV enfeksiyonun epidemiyolojisinde önemli rolleri vardır [83].

Klinik semptom gösteren atlarda ateş, ayaklarda zayıflık, ataksi, diş gıcırdatma, tremor, körlük ve kaslarda seğirme gibi belirtiler bildirilmiştir. Ayrıca ensefalit tablosuda gelişebilir. BNV enfeksiyonun- dan etkilenen atlarda ölüm oranı \%25 ile \%45 arasindadir $[82,84]$.

Kuşlarda klinik bulgular kalp kası yangısı, depresyon, uyuşukluk, tüylerde dökülme, kilo kaybı, ataksi ve felçtir. BNV çoklu organ hasarına da sebep olabilir. Beyin, kalp, akciğerler, böbrek, karaciğer, dalak, deri, gonadlar ve yemek borusu başlıca etkilenen organlardır [41]. Nörolojik semptom göstermeyen hasta hayvanlar tamamen iyileşirken, MSS semptomları gösterenlerde enfeksiyon uzun seyir gösterir ve bu durumlarda mortalite \%10'u aşar [71].

\section{Tedavi}

İnsanlarda standart bir tedavisi olmayan BNV enfeksiyonununda semptomatik tedavi uygulanır [4]. $\mathrm{Bu}$ sebeble, insanlarda hafif vakalarda ateşin düşürülmesi, baș/kas ağrısının giderilmesi ve bulantı/ kusmanın önlenmesi için antipiretik, analjezik ve antiemetik ilaçlar kullanılabilir [36,71].

Hastaneye yatırmayı gerektiren şiddetli vakalarda ise aşırı kusma durumunda intra venöz (IV) siv1 verilmesi, ileri derece kas zayıflaması durumunda entübasyon ve mekanik ventilasyon, sekonder enfeksiyon gelişmesinin önlenmesine yönelik tedavi, beyin ödeminin tedavisi/önlenmesi, gerekli ise antikonvülsan verilmesi ayrıca paraliz açısından değerlendirmeler yapılmalıdır[29,64].

Beyin ödemi ve herniasyona karşı kısa süreli steroid ve osmotik solüsyonlar kullanılmaktadır. Yapılan çalışmalarda, ribavirin, alfa-interferon $(\mathrm{IFN}-\alpha)$ ve pirazidin nükleozidleri gibi antiviral ajanların BNV'ye karşı in vitro aktiviteleri gösterilmiştir [2,37]. Yapılan bir çalışmada [37] yüksek doz ribavirinin in-vitro olarak insan oligodendroglial hücrelerine verilmesi sonucunda BNV replikasyonunun ve sitopatojenitesinin inhibe olduğu belirlenmiştir. Yapılan bu çalışmada ribavirin invitro olarak koruyucu bulunmuş ama tedavi edici etkisinin olmadığ 1 bildirilmiștir.

İnterferon alfa-2b (IFN- $\alpha 2 b)$ hücreye BNV ile enfekte olmadan önce veya sonra uygulandığında düşük dozda viral sitotoksisiteyi inhibe etmektedir. Farelerde yapılan çalışmalarda alfa ve beta interferonlarının BNV'ye karşı koruyucu olduğu gösterilmiştir. Araştırıcılar IFN- $\alpha 2 b$ ile meningoensefalitli olguların başarıyla tedavi edildiğini bildirmektedirler $[19,43]$. İnterferon alfa-2b, in-vitro olarak riba- 
virinden daha fazla tedavi edici aktiviteye sahiptir. Fakat hepatit $\mathrm{C}$ virus (HCV) enfeksiyonunun tedavisinde olduğu gibi kombine kullanım için ileri çalışmalara gerek olduğu vurgulanmaktadır [2]. Çünkü bu ajanların in-vivo kullanımı ile ilgili destekleyici/kontrollü klinik veriler mevcut değildir.

Bat1 Nil virusunun ABD'nde yüksek oranda nöroinvazif hastalık oluşturmasından dolayı son yıllarda yeni ve özgül antiviral ilaçların geliştirilmesi ile ilgili çalışmalar hız kazanmıştır [48]. 2004 yılından itibaren, özellikle virusun yapısal zarf proteinleri (prM ve E) ile NS3 (helikaz ve proteaz) ve NS5 (metiltransferaz ve RNA polimeraz) gibi yapisal olmayan proteinleri, hedef alınarak tedavi ve koruma amaçlı çalışmalara yoğunlaşılmıştır [70]. 2005 yılında plazmid tamanlı DNA aşısı geliştirilmiş ve aşının hayvan deneylerinde başarılı sonuçlar alınmıştır [21].

BNV'ye spesifik antikorları içeren yüksek doz intravenöz immünoglobulin uygulamasının, proflaktik ve terapötik etkinliği olduğu belirlenmiştir [7]. Yapılan deneylerdeki etkinliğine dayanarak salgınlar sirasinda insanlarda hiperimmüngamaglobulin uygulaması da bu sonuçları doğrulamıştır $[4,7,76]$.

Hayvanlardaki tedavide insanlarda olduğu gibi semptomatiktir, analjezik ve antipiretik ilaç kullanı1ır. Özellikle MSS semptomları gösteren atların çok sıkı tedavi ve takibi yapılmalıdır $[8,18]$.

\section{Aşı}

Günümüzde insanlarda kullanılmak üzere geliştirilmiş FDA onaylı ticari bir BNV aşısı henüz mevcut değildir. Fakat rekombinant canlı virus, alt ünite, DNA aşıları ve inaktive virus aşıları üzerinde çal1ş1maktadır [23,32].

Atlar için etkili ve lisanslı aşılar bulunmaktadır. Özellikle 6. ayın üstündeki atlarda kullanılan 4 adet lisanslı aşı vardır. Bunlar canlı attenüe aşılar, genetiği değişstirilmiş canlı virus aşıları, inaktif aşılar ve DNA aşılarıdır [4,23,32]. Atlarda kullanılan bu aşılardan birincisi, 2003 yılında lisans almış formalin ile inaktive tüm virus aşısı; diğeri ise 2004 yılında lisans almış rekombinant canlı canarypox virus aş1sıdır [23]. Bu iki aşının da atlarda viremiye karşı koruyuculuğu \%95-100 oranları arasında olduğu bildirilmiştir.
İnsanlarda kullanılmak amacıyla üzerinde çalışılan Rekombinant aşılarda primer hedef prM ve E yapısal proteinlerini kodlayan genlerdir. Ayrica yine prM ve E alt ünitelerinden oluşan ve enfeksiyöz olmayan virus benzeri partiküllerin (Virus Like Particles, VLP) kullanımı ile ilgili aşı çalışmalar1 da yapılmaktadır. Fakat VLP alt ünite aşılarının koruyucu immün yanıt oluşturmak için çok yükssek miktarlarda kullanılması büyük bir dezavantajdır $[4,78]$. Diğer taraftan humoral yanıtı iyi bir şekilde uyaran inaktif aşıların rutin uygulamalarında bazı olumsuzluklar vardır. Ekonomik olan ve humoral immuniteyi iyi şekilde uyaran attenüe aşıların ise immunsüprese kişilere uygulanması mümkün değildir $[23,42]$.

Canlı atenüe aşılarda olduğu gibi, in vivo olarak replike olabilen, viremiyi önleyebilen, kuvvetli nötralizan antikor yanıtı oluşturabilen ve tek bir immünizasyon ile etkin korumayı sağlayabilen değişik genetik kökenli kimerik aşılar umut verici sonuçlar doğurmuştur [23].

Günümüzde iki kimerik BNV aşısı üzerinde çalışmalar devam etmektedir. Bunlardan birincisi, uzun yıllar uygulanan güvenli ve etkili olduğu kanıtlanmış sarı humma virusu (YFV) 17D aş1sının vektör olarak kullanıldığı aşılardır [56]. Bu teknolojide, BNV yapısal protein genleri (WN-pr$\mathrm{M} / \mathrm{E}$ ), YFV 17D aşı suşuna karşılık gelen genlerinin (YF-prM/E) yerine yerleştirilmektedir. Bununla ilgili Amerika' daki çalışmalar şu anda faz Ive faz II aşamasında olup başarılı sonuçların alındığı belirtilmektedir [56]. Bir diğer canlı atenüe kimerik aşı ise, WN-prM/E genlerinin Dengue tip 4 virusuna entegrasyonu ile elde edilen aşı olup, faz I insan çalışmaları devam etmektedir [67].

\section{Korunma ve Kontrol}

Güvenilir ve etkili bir BNV aşısının eksikliği nedeniyle, hastalığın kontrol altında tutulabilmesi ve önlenebilmesi için dört önemli noktaya dikkat edilmelidir. Bunlar toplumsal düzeyde;

a)Atlardaki enfeksiyonun ve kuşlardaki ölümlerin izlenmesi,

b)Vektör sivrisineklerin larva haritalarının belirlenmesi ve sürekli bu bilgilerin güncel tutulmas1,

c)Ergin sivrisineklerin kontrolünün sağlanması,

d)Bireysel düzeyde korunma önlemlerinin alınması [40]. 
Kuşlarda yapılacak sürveyans çalışmaları, enfeksiyon durumunda diğer hayvanlar ve insanların korunmasında faydalı bilgiler sağlayabilir. $\mathrm{Bu}$ amaçla diğer kuşlara göre kargalar hastalığa çok duyarlı olduğu için sıklıkla ölü kargaların test edilebilmesi için insanlar tarafından karga ölümlerinin hemen en yakındaki veteriner hekimler ve ilgili sağlık kuruluşlarına bildirilmesi sağlanmalıdır [30].

Sivrisineklerin yumurtlayabileceği, içerisinde su birikebilecek bütün eșyaların ve kullanılmayan malzemelerin (teneke kutu, şişe, plastik kaplar, otomobil lastikleri, seyyar havuz vb) uygun şekilde imhası sağlanmalıdır. Ayrıca sivrisinek üreme alanlarında larvasitler ile ilaçlamalar yapılmalıdır.

Çatı veya teraslarda biriken suların boşaltılmasını sağlayan boruların ve yağmur oluklarının temizliği yapılmalı, tıkanıklığı kontrol edilerek, suların buralarda birikmesi engellenmelidir.

Sivrisinek yiyen balıklar süs havuzlarında bulundurulmalıdır.

Çöp kutuları, sarnıç, fosseptik çukuru, lağım çukuru ve variller bir kapakla sıkıca kapatılmalıdır.

Kapalı alanların pencere ve kapılarına sineklik takılmalı, bu uygulama ahırlarda da yapılmalıdır.

İnsan sağlı̆̆ 1 için zararsız olduğu bildirilen sivrisinek ve kene kovucu DEET (N,N-diethyl-m-toluamide) içeren repellentler kullanılmalıdır.

Şafak vakti ve gün batımı gibi sivrisineklerin aktif olduğu saatlerde dışarı çıkılmamalı; çıkılacaksa da uzun kollu ve pantolon gibi kapalı kiyafetler giyilmelidir. Aynı şekilde atlar da bu zaman dilimlerinde mümkünse dışarıda bırakılmamalıdır.

Enfeksiyonun epidemiyolojisi hakkında veteriner hekimlerin ayrıntılı bilgilendirilmesi ve sinir sisteminde enfeksiyon görülen at, köpek, kanatlı vs. hayvanların ihbar edilmelidirler.

Konuyla ilgili kamuoyunda farkındalık oluşturularak, vatandaşlara eğitimler verilmelidir $[30,71,81,84]$.

\section{Kaynaklar}

1. Alpert SG, Fergerson J, Noel LP, (2003). Intrauterine West Nile virus: ocular and systemicfindings. Am J Ophthalmol. 136, 733-735.

2. Anderson JF, Rahal JJ, (2002). Efficacy of interferon alpha$2 b$ and ribavirin against West Nile virus in vitro. Emerging infectious diseases. 8(1), 107-108.
3. Bagnarelli P, Marinelli K, Trotta D, Monachetti A, Tavio M, Del Gobbo R, Capobianchi MR, Menzo S, Nicoletti L, Magurano F, Varaldo PE, (2011). Human case of autochthonous West Nile virus lineage 2 infection in Italy, September 2011. Euro Surveill. 16(43), 1-4.

4. Bakır E, (2015). Batı Nil Virüsü Varlı̆̆ının Marmara Bölgesi Kan Donörlerinde Serolojik Ve Moleküler Yöntemler İle Araştırılmast. Yüksek Lisans Tezi, İstanbul Üniversitesi Cerrahpaşa Tıp Fakültesi Tıbbi Mikrobiyoloji ABD ve Tıbbi Viroloji Bilim Dalı, İstanbul.

5. Bakonyi T, Hubalek Z, Rudolf I, Nowotny N, (2005). Novel flavivirus or new lineage of West Nile virus, central Europe. Emerg. Infect. Dis. 11(2), 225-231.

6. Bakonyi T, Ivanics E, Erdelyi K, Ursu K, Ferenczi E, Weissenbock H, Nowotny N, (2006). Lineage 1 and 2 strains of encephalitic West Nile virus, central Europe. Emerg. Infect. Dis. 12(4), 618-623.

7. Ben-Nathan D, Gershoni-Yahalom O, Samina I, Khinich Y, Nur I, Laub O,Gottreich A, Simanov M, Porgador A, Zisman BR, Orr N, (2009). Using high titer West Nile intravenous immunoglobulin from selected Israeli donors for treatment of West Nile virus infection. BMC infectious diseases. 9, 18.

8. Biendenbender R, Bevilacqua J, Gregg AM, Watson M, Dayan G, (2011). Phase II, randomized, double-bling, placebo-controlled, multicenter study to investigate the immunogenicity and safety of a West Nile virüs vaccine in healthy adults. $\mathrm{J}$ Infect Dis. 203, 75-84.

9. Blut A, (2013). West Nile Virus. Transfus Med Hemother. 40, 265-284.

10. Bogachek MV, Zaitsev BN, Sekatskii SK, Protopopova EV, Ternovoi VA, Ivanova AV, Kachko AV, Ivanisenko VA, Dietler G, Loktev VB, (2010). Characterization of glycoprotein $E$ C-end of West Nilevirus and evaluation of its interaction force with alphaVbeta3 integrin asputative cellular receptor. Biochemistry. 75, 472-480.

11. Bondre VP, Jadi RS, Mishra AC, Yergolkar PN, Arankalle VA, (2007). West Nile virus isolates from India: evidence for a distinct genetic lineage. J. Gen. Virol. 88, 875-884.

12. Brington MA, (2014). Replication Cycle and Molecular Biology of the West Nile Virus, Viruses. 6, 13-53.

13. Bulașıcı Hastalıklar Sürveyans ve Kontrol Esasları YönetmeliğindeDeğişiklik Yapılmasına Dair Yönetmelik. Resmi Gazete; 02.04.2011 - 27893. http://www.resmigazete.gov.tr/eskiler/2011/04/20110402-3.htm Erişim tarihi:23.05.2016.

14. Bunning LM, Bowen AR, Cropp B, Sullivan GK, David SB, Komar N, Godsey SM, BakerD, Hettler LD, Holmes AD, Biggerstaff JB, Mitchell JC, (2002). Experimental infection ofhorses with west nile virus. Emerg Inf Dis. 8(4), 380-386.

15. Busch MR, Kleinman SH, Tobler LH, Kamel HT, Norris PJ, Walsh I, Matud JL, Prince HE, Lanciotti RS, Wright DJ, Linnen JM, Caglioti S, (2008). Virus and antibody dynamics in acute West Nile virüs infection. J. Infect. Dis. 198, 984-993.

16. Byrne SN, Halliday GM, Johnston LJ, King NJC, (2001). Interleukin-1beta but not tumornecrosis factor is involved in West Nile virus-induced Langerhans cell migration from the skin in C57BL/6 mice. 117(3), 702-709.

17. CDC, (2011). Expert consultation on West Nile virus infection. Thessaloniki, ECDC, 25-26 January 
18. CDC, (2013). West Nile Virus in the UnitedStates: Guidelines for Surveillance, Prevention, and Control, 4th Revision June 14.

19. Chan-Tack KM, Forrest G, (2005). Failure of interferon alpha-2b in a patient with West Nile virus meningoencephalitis and acute flaccid paralysis. Scand J Infect Dis. 37, 944-6.

20. Charatan F, (2002). Organ transplants and blood transfusions may transmit West Nile virus. BMJ. 14, 325(7364)- 566.

21. Colpitts TM, Conway MJ, Montgomery RR, Fikrig E, (2012). West Nile Virus: Biology, Transmission, and Human Infection. Clin Microbiol Rev. 25, 635-648.

22. Cunha BA, (1999). West Nile Encephalitis. Infectious Disease Practice for Clinicians. 23(10), 85-89.

23. Dauphin G, Zientara S, (2007). West Nile virus: Recent trends in diagnosis andvaccine development. Vaccine. 25, 55635576.

24. Debiasi RL, (2011). West Nile virus neuroinvasive disease. Curr Infect Dis Rep. 13(4), 350-359.

25. Diamond SM, (2003). Evasion of innate and adaptive immunite by flavivirus. Immunol and Cell Biol. 81, 196-206.

26. Duran B, Chevalier V, Pouillot R, Labie J, Marendat I, Murgue B, Zeller H, Zientara S, (2002). West nile virus outbreak in horses, Southern France, 2000: Results of serosurvey. Emerg Infect Dis. 8(8), 777-782.

27. Erdem H, Pahsa A, (2003). Yeni bir pandemi mi ? Batı Nil virüs enfeksiyonu. İnfeksiyon Dergisi. 17, 245-249.

28. Ergünay K, (2010). Batı Nil Virusu: Viroloji, Epidemiyoloji ve Mikrobiyolojik Tanı. III Türkiye Zoonotik Hastalıklar Sempozyumu; Ankara.

29. Ergünay K, Aydoğan S, Menemenlioğlu D, (2010). Ankara Bölgesinde Nedeni Bilinmeyen Merkezi Sinir Sistemi Enfeksiyonlarında Batı Nil Virüsünün Araştırılması. Mikrobiyol Bul. 44, 255-262.

30. Ertürk A, (2010). Batı Nil virüsü enfeksiyonunda korunma ve kontrol. III Türkiye Zoonotik Hastalıklar Sempozyumu. 166173.

31. Gyure KA, (2009). West Nile virus infections. J. Neuropath. Exp. Neur. 68, 1053-1060.

32. Hall RA, Khromykh AA, (2004). West Nile virus vaccines. Expert Opin Biol Ther. 4, 1295-1305.

33. Hayes EB, Sejvar JJ, Zaki SR, Lanciotti RS, Bode AV, Campbell GL, Lanciotti RS, Bode AV, Campbell GL, (2005). Virology, pathology and clinical manifestations of West Nile virus disease. Emerg. Infect. Dis. 11, 1174-1179.

34. Heinz FX, Collett MS, Purcell RH, Gould EA, Howard CR, Houghton M,Moormann RJM, Rice CM, Thiel HJ, (2000). Family: Flaviviridae. Ed(s) Van Regenmortel MHV, Fauquet CM,Bishop DHL, Carstens EB, Estes MK, Lemon SM, et al. eds. Virustaxonomy: classification and nomenclature of viruses. 7th Report of theInternational Committee on Taxonomy of Viruses. San Diego, Academic Press, p. 859-878.

35. Hızel K, Yenicesu İ, Erdal B, Yeşilyurt E, Fidan I, Kalkancı A, Dilsiz G, (2010). Investigation of West Nile virus seroprevalence in healthy blood donors. Mikrobiyol. Bul. 44, 425-430.

36. Huhn GD, Sejvar JJ, Montgomery SP, Dworkin MS, (2003). West Nile virus in theUnited States: an update on an emerging infectious disease. Am Fam Physician. 68, 653-660.
37. Jordan I, Briese T, Fischer N, Lau JY, Lipkin WI, (2000) Ribavirin inhibits West Nile virus replication and cytopathic effect in neural cells. The Journal of infectious diseases. 182(4), 1214-1217.

38. Kalaycığlu H, (2010). Türkiye'de görülen West Nile vakalarının epidemiyolojisi. III. Türkiye Zoonotik Hastalıklar Sempozyumu, Ankara, Türkiye, 1-2 Kasım 2010, 174-183.

39. Kalaycioglu H, Korukluoglu G, Ozkul A, Oncul O, Tosun S, Karabay O, Gozalan A, Uyar Y, Caglayık DY, Atasoylu G, Altas AB, Yolbakan S, Ozden TN, Bayrakdar F, Sezak N, Pelitlı TS, Kurtcebe ZO, Aydın E, Ertek M, (2012). Emergence of West Nile virüs infection in humnas in Turkey, 2010 to 2011. Eurosurveillance. 17, p. 20182.

40. Kılıç A, Doğancı L, (2003). Batı Nil Virus. Türk Mikrobiyoloji Cemiyeti Dergisi. 33, 284-290.

41. Komar N, Langevin S, Hinten S, Nemeth N, Edwards E, Hettler DL, Davis BS, Bowen RA, Bunning ML, (2003). Experimental infection of North American birds with the New York 1999 strain of West Nile virus. Emerg. Infect. Dis. 9(3), 311-322.

42. Lanciotti SR, Kerst JA, Nasci SR, Godsey MS, Mitchell CJ, Savage HM, Komar N, Panella NA, Allen BC, Volpe KE, Davis BS, Roehrig JT, (2000). Rapid detection of West Nile Virus from human clinical specimens, field-collected mosquitoes, and avian samples by a TaqMan reverse transcriptasePCR assay. J Clin Microbiol. 38, 4066-4071.

43. Lewis M, Amsden JR, (2007). Successful treatment of West Nile virus infection after approximately 3 weeks into the disease course. Pharmacotherapy. 27, 455-458.

44. Lim P-Y, Behr MJ, Chadwick CM, Shi P-Y, Bernard KA, (2011). Keratinocytes are cell targets of west nile virus in vivo. J. Virol. 85(10), 5197-5201.

45. Lim SM, Koraka P, Osterhaus AD, Martina BE, (2011). West Nile virus: immunity and pathogenesis. Viruses. 3(6), 811828.

46. Lindenbach BD, Thiel HJ, Rice CM, (2007). Flaviviridae. In Fields virology, vol $1,5^{\text {th }}$ ed. In Knipe DM, Howley PM, eds. (Lippincott Williams \& Wilkins:Philadelphia). p. 1101-1113.

47. Lindenbach BD, Murray CI, Thiel HJ, Rice CM, (2013). Flaviviridae. Fields Virology, $6^{\text {th }}$ Ed. In Knipe DM, Howley PM, eds. (Lippincott Williams \& Wilkins, Philadelphia). p. 712-746.

48. Lindsey NP, Staples JE, Lehman JA, Fischer M, (2010). Centers for Disease Control and Prevention (CDC). Surveillance for human West Nile virus disease - United States, 1999-2008. MMWR Surveill Summ. 59, 1-17.

49. Lvov DK, Butenko AM, Gromashevsky VL, Kovtunov AI, Prilipov AG, Kinney R, Aristova VA, Dzharkenov AF, Samokhvalov EI, Savage HM, Shchelkanov MY, Galkina IV, Deryabin PG, Gubler DJ, Kulikova LN, Alkhovsky SK, Moskvina TM, Zlobina LV, Sadykova GK, Shatalov AG, Lvov DN, Usachev VE, Voronina AG, (2004). West Nile virus and other zoonotic viruses in Russia: examples of emergingre emergingsituations. Arch Virol Suppl. 18, 85-96.

50. Mackenzie JS, Williams DT, (2009). The zoonotic flaviviruses of southern, south-easternand eastern Asia, and Australasia. the potential for emergent viruses. Zoonoses Public Health. 56(6-7), 338-356. 
51. Marfin AA, Gubler DJ, (2001). West Nile encephalitis: an emerging disease in the United States. Clinical infectious diseases: an official publication of the Infectious Diseases Society of America. 33(10), 1713-1719.

52. May FJ, Davis CT, Tesh RB, Barrett ADT, (2011). Phylogeography of West Nile virus: from the cradle of evolution in Africa to Eurasia, Australia, and the Americas. J Virol. 85(6), 2964-2974.

53. Meço O, (1975). Güney Doğu Anadolu ve Doğu Karadeniz Bölgeleri Halkında Arbovirus Hemaglütinasyon-İnhibisyon Antikorlarının Araştırılması. Doçentlik Tezi, Ankara Üniversitesi Tıp Fakültesi, Ankara.

54. Meço O, (1977). Güneydoğu Anadolu halkında Batı Nil ateşi hemaglütinasyon önlenim antikorlarının araștırılması. Mikrobiyol. Bul. 11, 3-17.

55. Monath PT, Heinz XF, (1996). Flaviviruses. In: Pields NB, Knipe DM, Howley MP, Chanock RM, Melnick LJ, Monath PT, Poizman B, Strauss ES. Field's Virology, 3 rdedition, Philedelphia, Lippincott-Raven. p. 961-1034.

56. Monath TP, Liu J, Kanesa-Thasan N, Myers GA, Nichols R, Deary A,McCarthy K, Johnson C, Ermak T, Shin S, Arroyo J, Guirakhoo F, Kennedy JS, Ennis FA, Green S, Bedford P, (2006). A live, attenuated recombinant West Nile virus vaccine. Proc Natl Acad Sci USA. 103, 6694-6699.

57. Monini M, Falcone E, Busani L, Romi R, Ruggeri FM, (2010). West Nile virus: Characteristics of an African virus adapting to the third millennium world. Open Virol. J. 22, 42-51.

58. Murgue $\mathrm{B}$, Murri $\mathrm{S}$, Triki $\mathrm{H}$, (2001). West Nile in the Mediterranean basin: 1950-2000. Ann NY Acad Sci. 951, 117-126.

59. Murray KO, Mertens E, Despres P, (2010). West Nile virus and its emergence in the United States of America. Vet Res. $41,67$.

60. Murray KO, Walker C, Gould E, (2011). The virology, epidemiology, and clinicalimpact of West Nile virus: A decade of advancements in resarch since itsintroduction into Western Hemisphere. Epidemiol Infect. 139, 807-817.

61. Nosal B, Pellizzari R, (2003). West Nile Virus. CMAJ. 168, 1443-1444.

62.O'Leary DR, Marfin AA, Montgomery SP, Kipp AM, Lehman JA, Biggerstaff BJ, Elko VL, Collins PD, Jones JE, Campbell GL, (2004). The epidemic of West Nile virus in the United States. Vector Borne Zoonotic Dis. 4, 61-70.

63. Ozkul Aykut, Ergunay Koray, Koysuren Aydan, Alkan Feray, Arsava Ethem M., Tezcan Seda, Emekdas Gurol, Hacioglu Sabri, Turan Mahur, Us Durdal, (2013). Concurrent occurrence of human and equine West Nile virus infections in Central Anatolia, Turkey: the first evidence for circulation of lineage 1 viruses. International Journal of Infectious Diseases 17, 546-551

64. Petersen LR, Brault AC, Nasci RS, (2013). West Nile Virus: Review of the Literature. JAMA. 310(3), 308-315.

65. Petersen LR, Marfin AA, (2002). West Nile Virus: A primer for the clinician. Ann Intern Med. 137, 173-179.

66. Pierson TC, Diamond MS, (2012). Degrees of maturity : the complex structure andbiology of flaviviruses. Curr Opin Virol. 2, 168-175.
67. Pletnev AG, Claire MS, Elkins R, Speicher J, Murphy BR, Chanock RM, (2003). Molecularly engineered live-attenuated chimeric West Nile/dengue virus vaccines protect rhesus monkeys from West Nile virus. Virology. 314, 190-195.

68. Reiter P, (2010). West Nile virus in Europe: understanding the present to gauge the future. Euro Surveill. 15, 19508.

69. Rossi S, Ross TM, Evans JD, (2010). West Nile virus. Clin. Lab. Med. 30, 47-65.

70. Sampath A, Padmanabhan R, (2009). Molecular targets for flavivirus drug discovery. Antiviral Res. 81, 6-15.

71. Sampathkumar P, (2003). West Nile Virus: Epidemiology, clinical presentation, diagnosis and prevention. Mayo Clin. Proc. 78, 1137-1144.

72. Samuel MA, Diamond MS, (2006). Pathogenesis of West Nile virus infection: abalance between virulence, innate and adaptive immunity, and viral evasion. J Virol. 80, 9349-9360.

73. Sanchez MD, Pierson TC, McAllister D, Hanna SL, Puffer BA, ValentineLE, Murtadha MM, Hoxie JA, Doms RW, (2005). Characterization of neutralizing antibodies to West Nile virus. Virology. 336(1), 70-82.

74. Savini G, Capelli G, Monaco F, Polci A, Russo F, Di Gennaro A,Marini V, Teodori L, Montarsi F, Pinoni C, Pisciella M, Terregino C, Marangon S, Capua I,Lelli R, (2012). Evidence of West Nile virus lineage 2 circulation in northern Italy. Vet. Microbiol. Aug 17. 158(3-4), 267-273.

75. Shi PY, Kramer LD, (2003). Molecular detection of West Nile virus RNA. Expert Review of Molecular Diagnostics.n3, 357366.

76. Shimoni Z, Niven MJ, Pitlick S, Bulvik S, (2001). Treatment of West Nile virus encephalitis with intravenous immunoglobulin. Emerging infectious diseases. 7(4), 759.

77. Smithburn K, Hughes T, Burke AA, (1940). neurotropic virus isolated from theblood of a native of Uganda. Am J Trop Med. 20, 471-492.

78. Spohn G, Jennings GT, Martina BE, Keller I, Beck M, Pumpens P,Osterhaus AD, Bachmann MF, (2010). A VLPbased vaccine targeting domain III of the West Nile virus $E$ protein protects from lethal infection in mice. Virol J. 7, 146.

79. Taylor RM, Work TH, Hurlbut HS, (1956). A study of the ecology of West Nilevirus in Egypt. Am J Trop Med. 5, 579-62013.

80. Tezcan S, Ülger M, Emekdaş G, (2011). Batı Nil Virusu ve infeksiyonu. Mersin Üniv Sağlık Bilim Derg. 4(3), 9-17

81. Tosun S, (2010). Batı Nil virüsü enfeksiyonunda klinik ve tedavi. III. Türkiye Zoonotik Hastalıklar Sempozyumu, Ankara, Türkiye, 1-2 Kasım 2010, 161-165.

82. Weiss D, Carr D, Kellachan J, Tan C, Phillips M, Bresnitz E,Layton M, and West Nile Virus Outbreak Response Working Group (2001). Clinical findings of West Nile Virus infection in hospitalized patients, New York and New Jersey 2000. Emerg Infect.Dis. 7, 654-659.

83. www.cvma.net/publications/press-releases/west-nile-virusin-dogs-cats/ Erişim Tarihi: 25.10.2016.

84. Yazıcı Z, (2005). Batı Nil Virusu infeksiyonu. İnfeksiyon Dergisi (Turkish Journal of Infection). 19 (1), 139-143. 